\title{
Erratum to: Soil criteria to protect terrestrial wildlife and open-range livestock from metal toxicity at mining sites
}

\author{
Karl L. Ford • W. Nelson Beyer
}

Published online: 30 January 2014

C) Springer Science+Business Media Dordrecht 2014

\section{Erratum to: Environ Monit Assess}

DOI: $10.1007 / \mathbf{s} 10661-013-3503-x$

Karl Ford is retired from the Bureau of Land Management and the original published article does not reflect official policy of the Bureau of Land Management.

The online version of the original article can be found at http://dx. doi.org/10.1007/s10661-013-3503-x.

\section{K. L. Ford}

Bureau of Land Management, 26 S. Mt. Vernon Country Club Rd, Golden, CO 80401, USA

W. N. Beyer $(\bowtie)$

U.S. Geological Survey, Patuxent Wildlife Research Center, BARC East, Bldg. 308, 10300 Baltimore Ave, Beltsville, MD 20705, USA

e-mail: nbeyer@usgs.gov 